\title{
Assessment of Sensitivities to Anilinopyrimidine- and Strobilurin-fungicides in Populations of the Apple Scab Fungus Venturia inaequalis
}

\author{
S. KUNZ, B. LUTZ, H. DEISING and K. MENDGEN \\ Authors' address: Universitat Konstanz, Fakultat für Biologie, Lehrstuhl für Phytopathologie, Universitatsstr. 10, \\ D-78434 Konstanz, Germany (correspondence to K. Mendgen) \\ With 5 figures \\ Received November 26, 1997; accepted December 1, 1997
}

\begin{abstract}
The sensitivity of Venturia inaequalis populations to the anilinopyrimidine fungicides pyrimethanil and cyprodinil was analysed by microscopic in vivo analysis of conidiophore formation. The sensitivity to the strobilurin kresoxim-methyl was analysed using an in vitro germination assay and by determination of the diseased leaf area and conidia produced in vivo. Baseline sensitivities were determined with $V$. inaequalis populations from control orchards that had never been treated with fungicides. Comparison of the baseline sensitivities with sensitivities ofpopulations obtained from orchards that had received 43 anilinopyrimidine treatments over 4 years, or from an orchard with 54 kresoxim-methyl treatments over 6 years indicated that no resistance to these fungicides has developed at the sites sampled.
\end{abstract}

\section{Zusammenfassung}

Erfassung der Sensitivitliten gegeniiber Anilinopyrimidin- und Strobilurinfungiziden in Populationen des Apfelschorfpilzes (Venturia inaequalis)

Die SensitiviHit von Venturia-inaequalis-Populationen gegenuber den Anilinopyrimidinfungiziden Pyrimethanil und Cyprodinil wurde durch eine mikroskopische in-vivoAnalyse der Konidiophorenbildung analysiert. Die Sensitivitat gegenuber dem Strobilurin Kresoxim-methyl wurde mittels eines in-vitro-Keimtests sowie durch eine Bestimmung der erkrankten Blattflache und der Konidienbildung in vivo erfaBt. Die Basissensitivitaten wurden mit Hilfe von $V$-inaequalis-Populationen aus KontrollApfelanlagen ermittelt, die noch nie mit Fungiziden behandelt worden waren. Ein Vergleich der Basissensitivitaten mit den Sensitivitaten von Populationen aus Apfelanlagen, die in 4 Jahren insgesamt 43 Anilinopyrimidinbehandlungen erhalten hatten, sowie aus einer Apfelanlage, die in 6 Jahren insgesamt 54 Kresoximmethylbehandlungen erhalten hatte, ergab, daB sich an den untersuchten Standorten keine Resistenz gegen diese Fungizide ausgebildet hatte.

\section{Introduction}

The significance of Venturia inaequalis in Germany is indicated by the fact that up to 20 fungicide treatments are performed per season to chemically control apple scab disease (Kollar, 1997). Until 1995, only one group of fungicides with a specific mode of action, the curative sterol demethylation inhibitors (DMIs), was available in addition to nonspecific protective fungicides in Germany. Two years ago the anilinopyrimidine pyrimethanil, and last year the strobilurin kresoxim-methy1 were introduced to control $V$ inaequalis in Germany.

Anilinopyrimidine fungicides have both a protective and a curative effect on apple scab, due to the strong inhibition of subcuticular growth of the fungus (Daniels et aI., 1994; Knauf-Beiter et aI., 1995). Whilepyrimethanil has been registered for scab control in Germany since 1996, cyprodinil is currently being tested against apple pathogens such as Venturia, Alternaria, and Monilinia (Heye et aI., 1994).

The strobilurin kresoxim-methyl inhibits the spore germination of $V$ inaequalis and can thus be regarded as a protective fungicide (Gold et aI., 1996). Like DMIs and benzimidazoles, strobilurins have one specific target in fungal metabolism and can thus be regarded as specific fungicides (Becker et aI., 1981; Gold et aI., 1996).

The fact that resistance to several fungicide classes has occurred in $V$ inaequalis populations treated with the respective fungicides (Fehrmann, 1976; Gilpatrick, 1982; Kiebacher and Hoffmann, 1980; Koller et aI., 1997; Kunz et aI., 1997), makes an assessment of the level of the sensitivity to new fungicides such as the anilinopyrimidines and strobilurins necessary. To accomplish this, methods are needed that allow the baseline sensitivity for these fungicides in untreated $V$ inaequalis populations to be determined, and shifts in sensitivity levels need to be followed after fungicide applications (Koller et aI., 1997; Kunz et aI., 1997; Siebels and Mendgen, 1994).

Several methods have been used to analyse fungicide efficiencies. Examples are spore germination assays or 
radial growth measurements in the presence of different fungicide concentrations and determination of the minimal inhibitory fungicide concentration on agar plates (Gold et al., 1996; Hildebrand et al., 1988; Smith, 1991; Smith et al., 1991). Such in vitro assays may be used to analyse the effects of the protective strobilurins which inhibit spore germination, but they are inappropriate when the mechanism of the fungicide to be tested is related to infection or growth within the plant, e.g. for anilinopyrimidines.

Siebels and Mendgen (1994) have developed a microscopic in vivo method to assess the efficiencies of curative fungicides, and Kunz et al. (1997) have demonstrated that this method is appropriate to monitor the development of DMI-fungicide resistances at the population level. Since this method has the advantage that fungicide sensitivities of populations rather than of isolates are seen, and since fungal virulence and susceptibility of the plant tissue contribute to the results of this in vivo assay, this method is particularly suited to analyse fungal sensitivity against curative fungicides.

This paper describes the determination by in vivo and in vitro methods of the baseline sensitivities of $V$. inaequalis populations without fungicide history for the anilinopyrimidines pyrimethanil and cyprodinil, and for the strobilurin kresoxim-methyl. Sensitivities in populations treated with fungicides for up to 6 years were compared with the baseline sensitivity.

\section{Materials and Methods Test plants}

Potted apple trees (Malus domestica) of the cultivar Golden Delicious, grafted on M 25 rootstocks at the Schweizerischen Forschungsanstalt für Obst und Weinbau, Wädenswil, Switzerland, were kept in a greenhouse at $18-25^{\circ} \mathrm{C}$ and a $16 \mathrm{~h}$ light period. The trees were fertilized weekly with $0.1 \%$ Hakaphos red $(\mathrm{N}: \mathrm{P}: \mathrm{K}=$ $8: 12: 24)$ and $0.1 \%$ Hakaphos blue $(\mathrm{N}: \mathrm{P}: \mathrm{K}=$ $15: 10: 15)$ (Compo GmbH, Münster, Germany).

\section{Fungicides}

The anilinopyrimidines pyrimethanil (Scala EC 40; AgrEvo $\mathrm{GmbH}$, Düsseldorf, Germany) and cyprodinil (CGD 20470 F WG 50; Ciba Geigy GmbH, Frankfurt/M., Germany), and the strobilurin kresoxim-methyl (BAS 490 F WG 50; BASF AG, Limburgerhof, Germany) were provided by the manufacturing companies as formulated test preparations. The DMI fungicide flusilazole (Benocap WG 20; DuPont de Nemours GmbH, Bad Homburg, Germany) and the protective fungicide dithianon (Delan SC 750; Cyanamid Agrar, Ingelheim, Germany) were used as commercial formulations.

\section{Inoculum}

The inoculum was collected in six apple orchards at different locations in the Lake Constance area, BadenWürttemberg, Germany, and with different fungicide histories. Orchard 1 (located at Öschingen, with the apple variety Golden Delicious) and orchard 2 (Konstanz, Golden Delicious) served as control orchards that had never been treated with fungicides. Orchard 3 (Litzelstetten, Golden Delicious) and orchard 4 (Lindau, Jonagold) are managed according to integrated control guidelines. From 1993 to 1995 , between 13 and 17 fungicide treatments had been performed per season in these orchards. Until the last sampling in 1995, neither anilinopyrimidines nor strobilurins had been applied in orchards 3 and 4. Orchard 5 (Überlingen, Golden Delicious) is part of a test orchard of the Amtliche Pflanzenschutzberatung, a national advisory service, divided into four plots A, B, C and D with 20 apple trees each. Fungicide treatments performed in this test orchard are given in detail in Table 1. Orchard 6 is a test orchard of BASF AG (Ludwigshafen, located in Bavendorf, Baden Württemberg) with Golden Delicious trees. Small plots of three trees each have been used to test different kresoximmethyl concentrations and fungicide formulations since 1990. Leaves with scab lesions were collected in 1996 from control trees, untreated in 1996. However, 10, 8, 8, 10,10 and 8 kresoxim-methyl treatments were performed in 1990, 1991, 1992, 1993, 1994 and 1995, respectively.

To compare sensitivity levels of $V$. inaequalis populations with different fungicide histories, naturally infected leaves with sporulating scab lesions were collected from the test orchards and stored in plastic bags at $-70^{\circ} \mathrm{C}$. Conidial suspensions were obtained by shaking the thawed leaves in $100 \mathrm{ml}$ of deionized water. To obtain ascospores, naturally infected leaves were collected in November and overwintered in wire mesh cases on the ground of the orchard. The overwintered leaves were analysed for development of pseudothecia, beginning at the end of February of the following year. Apple leaves with pseudothecia containing 5-10\% mature ascospores were collected on March 6, 1995 and April 22, 1996 and stored in plastic bags at $-70^{\circ} \mathrm{C}$. To obtain ascospore suspensions, the leaves were thawed and incubated in a dark moist chamber for 10 days at $20^{\circ} \mathrm{C}$. Leaves containing mature, preconditioned pseudothecia were then washed in deionized water for 10 minutes and placed upside down in a glass Petri dish $(14.5 \mathrm{~cm})$, filled with $30 \mathrm{ml}$ deionized water. The Petri dish was illuminated with $1800 \mathrm{~lx}$ from beneath for $1 \mathrm{~h}$ at $+5^{\circ} \mathrm{C}$ to allow ascospore discharge into the water (Smereka et al., 1987). The conidia or ascospores from one orchard collected during 1 day are referred to as a sample.

\section{In vitro sensitivity test based on spore germination}

To avoid fungicide contaminations in conidial suspensions obtained from treated orchards, conidia were propagated in the greenhouse as described (Kunz et al., 1997).

Spore suspensions $\left(10^{5}\right.$ spores $\left./ \mathrm{ml}\right)$ were adjusted to contain different kresoxim-methyl concentrations $(0.625 \mu \mathrm{g}-0.625 \mathrm{mg} / 1)$ and applied to microscope slides. Duplicates of each treatment were incubated at $100 \%$ relative humidity at $20^{\circ} \mathrm{C}$. Each fungicide concentration was incubated in a separate chamber to avoid obscuring results, due to vapour diffusion (Gold et al., 1996). The percentage of germinated conidia was determined by counting 200 specimens per microscope slide after $24 \mathrm{~h}$. 
Table 1

Number of fungicide treatments in orchard 5 from 1993 to 1996. Only one fungicide was used per plot and season. Recommended fungicide doses (62.5 mg kresoxim-methyl/1; $300 \mathrm{mg}$ pyrimethanil/1 and $150 \mathrm{mg}$ cyprodinil/l) were applied

\begin{tabular}{|c|c|c|c|c|c|c|c|c|}
\hline \multirow[t]{2}{*}{ Plot } & \multicolumn{2}{|c|}{1993} & \multicolumn{2}{|c|}{1994} & \multicolumn{2}{|c|}{1995} & \multicolumn{2}{|l|}{1996} \\
\hline & Fungicide & $\mathrm{n}^{a}$ & Fungicide & $\mathrm{n}^{\mathrm{a}}$ & Fungicide & $n^{a}$ & Fungidice & $\mathrm{n}^{\mathrm{b}}$ \\
\hline A & Pyrimethanil & 12 & Cyprodinil & 10 & Cyprodinil & 14 & Cyprodinil & 7 \\
\hline B & - & & - & & Pyrimethanil & 14 & Pyrimethanil & 7 \\
\hline $\mathrm{C}$ & - & & Pyrimethanil & 8 & - & & - & \\
\hline $\mathrm{D}$ & - & & Kresoxim-methyl & 11 & Kresoxim-methyl & 11 & Kresoxim-methyl & 5 \\
\hline
\end{tabular}

Number of treatments; ${ }^{b}$ Number of treatments until sampling (July 1, 1996).

The means of efficiencies were used to determine doseresponse curves.

In vivo sensitivity test based on determination of the portion of diseased leaf area and the amount of conidia formed

Solutions containing different kresoxim-methyl concentrations $(0.208-62.5 \mathrm{mg} / \mathrm{l})$ were applied to four shoots until run off. Control plants were sprayed with deionized water. Twenty-four hours after the fungicide or control treatments, the plants were spray inoculated with $10^{5}$ conidia/ml and subsequently incubated at $18^{\circ} \mathrm{C}$ and $100 \%$ relative humidity for $28 \mathrm{~h}$ in the dark. The plants were subsequently kept under greenhouse conditions as described above. Sixteen days after inoculation, the proportion of diseased leaf area of the three youngest inoculated leaves was determined (Dahmen and Staub, 1992), and these three leaves were shaken in $30 \mathrm{ml}$ of deionized water for $1 \mathrm{~min}$ in order to obtain a conidial suspension. The conidial concentration was determined with a haematocytometer, and conidia formed were based on the leaf fresh weight (Dahmen and Staub, 1992). In total, the diseased leaf area of 36 leaves was assessed per fungicide concentration, and 12 shoots per fungicide concentration were analysed with respect to production of conidia. The resulting fungicide efficiencies were used to plot dose-response curves.

In vivo sensitivity test based on microscopic evaluation of conidiophore formation

Microscopic in vivo assays were performed as described by Kunz et al. (1997). Briefly, the plants were spray inoculated $\left(10^{5} / \mathrm{ml}\right)$, and the inoculated plants were incubated in the dark at $18^{\circ} \mathrm{C}$ and $100 \%$ relative humidity for $24 \mathrm{~h}$. Different fungicide concentrations $(10-300 \mathrm{mg} / 1 \mathrm{pyr}-$ imethanil or $5-150 \mathrm{mg} / \mathrm{l}$ cyprodinil) were applied by spraying with a glass atomizer $28 \mathrm{~h}$ after inoculation. Three shoots were used per treatment; the controls were sprayed with deionized water.

Six days after inoculation the two youngest inoculated leaves per shoot were glutaraldehyde-fixed, bleached and stained with methyl blue (Kunz et al., 1997). One-hundred infection sites were evaluated at $200 \times$ magnification, and the reduction of conidiophore formation as depending on fungicide concentration was taken as a measure for fungicide sensitivity of $V$. inaequalis populations.

\section{Data analysis}

Different dose-response relationships were statistically compared with a factorial analysis using ranks (Meddis, 1984) with a macro written by Dr W. Nagl, Universität Konstanz, under SAS (Statistical Analysis System, SAS Institute, Inc., Cary, NC, USA). Dose-response relationships were considered significantly different at $P<0.01$. The averages of the efficiencies were logit-transformed $(\operatorname{logit}$ efficiency $=\ln$ (efficiency $/ 1.0$-efficiency) $($ Neter et al., 1983). Efficiencies of $100 \%$ had to be modified before logit-transformation. In microscopic evaluations, modified efficiency equals $1-1 / 2 n$, in which $n$ was the number of all infection sites in this treatment (Neter et al., 1983). A linear regression using the regression programme of the 'Statistica for Macintosh' (Statsoft Inc., Tulsa, OK, USA) between the logit-transformed efficiencies and the logarithm of the fungicide concentration revealed the $\mathrm{ED}_{50^{-}}$and the $\mathrm{ED}_{90^{-}}$-value of the sample. The resistance factor was calculated by dividing the $\mathrm{ED}_{50}$-value of the sample by the $\mathrm{ED}_{50}$-value of the baseline sensitivity.

Different developmental stages of $V$. inaequalis were determined in the percentage of conidia that had germinated on the leaf. The means of a treatment were compared using the Mann-Whitney $U$-test (Nonparametrics of Statistica for Macintosh; Statsoft). The means were considered significantly different at $\mathrm{P}<0.05$.

\section{Results \\ Inhibition of $V$. inaequalis at different developmental stages by different fungicides}

The effect of the strobilurin kresoxim-methyl and of the anilinopyrimidines pyrimethanil and cyprodinil on spore gemination were compared with the inhibitory effects of the contact fungicide dithianon and the DMI fungicide flusilazole (Table 2). Both, kresoxim-methyl and dithianon blocked spore germination in the in vitro assays, using the recommended fungicide concentrations, indicating that such assays can thus be used to determine the kresoxim-methyl sensitivity of $V$. inaequalis populations. Both, anilinopyrimidines and the DMI fungicide tested had a negligible effect on spore germination at recommended concentrations.

Microscopic in vivo assays were used to investigate the inhibitory effects of the anilinopyrimidines in comparison to the DMI flusilazole on $V$. inaequalis infection structure 
Table 2

Efficiency of fungicides determined by in vitro germination assays. Conidia of Venturia inaequalis were collected from control orchard 1 and allowed to germinate on glass microscope slides in the presence of recommended fungicide concentrations.

Germination in deionized

water served as control

\begin{tabular}{lccr}
\hline Fungicide & Concentration $(\mathrm{mg} / \mathrm{l})$ & Germination rate $(\%)$ & Efficiency \\
\hline Water & & 56.4 & 99 \\
Kresoxim-methyl & 62.50 & 0.3 & 27 \\
Pyrimethanil & 300 & 41.0 & -1 \\
Cyprodinil & 150 & 57.1 & 0 \\
Flusilazole & 25 & 56.5 & 100 \\
Dithianon & 450 & 0 & 0 \\
\hline
\end{tabular}

differentiation. Apple leaves had been treated with fungicides either 1 day prior to inoculation, or, to demonstrate the curative effects, 1, 2 or 3 days post-inoculation. Pyrimethanil and cyprodinil only weakly inhibited the germination and penetration hypha differentiation on host leaves, but differentiation of subcuticular structures, i.e. primary subcuticular stroma, runner hyphae and secondary subcuticular stroma, was almost completely blocked in the presence of these fungicides (Fig. 1). When

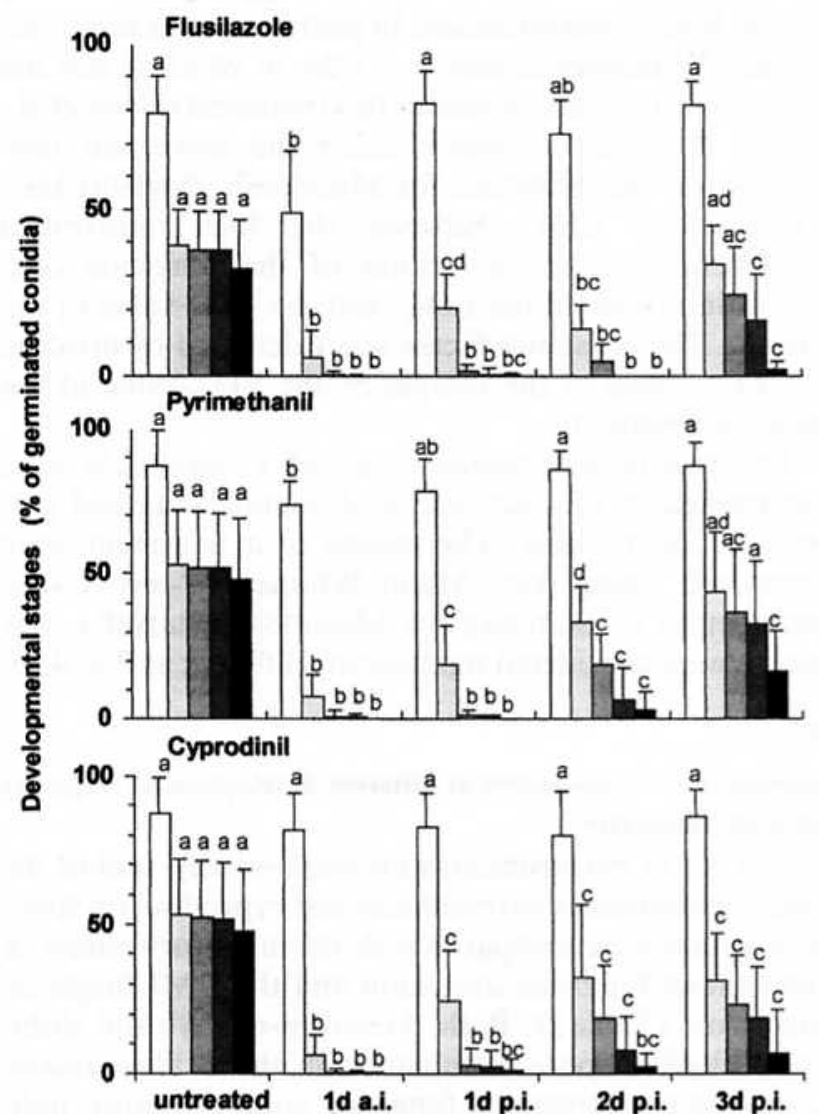

Fig. 1 Development of Venturia inaequalis on apple leaves treated with different fungicides. Flusilazole $(25 \mathrm{mg} / \mathrm{l})$, cyprodinil $(150 \mathrm{mg} / \mathrm{l})$ or pyrimethanil $(300 \mathrm{mg} / \mathrm{l})$ were applied to the leaves 1 day before $(1 \mathrm{~d}$ a.i.), 1, 2 or 3 days after inoculation (1, 2 or $3 \mathrm{~d}$ p.i.) with conidia collected from control orchard 1. Penetration pores ( $\square$ ), primary stroma ( $)$, runner hyphae $(\mathbb{E})$, secondary stroma (E), and conidiophores ( $\square$ ) were counted 6 days after inoculation. The columns represent means of 10 leaves; bars represent standard errors. Different letters over the columns indicate significant differences in the respective developmental stage $(P<0.05)$ according to the Mann-Whitney $U$-test the fungicides were applied 1 day after inoculation, the development of primary subcuticular stroma and especially of runner hyphae were inhibited (Fig. 1).

These results indicate that microscopic in vivo assays based on conidiophore formation (Kunz et al., 1997) are appropriate to test for shifts in the anilinopyrimidine sensitivity of $V$. inaequalis populations.

Sensitivity of $V$. inaequalis populations to the strobilurin fungicide kresoxim-methyl

Baseline sensitivity was determined in in vitro germination assays, using eight samples from four orchards without strobilurin history (Table 3 ). The $\mathrm{ED}_{50}$-values of these samples varied from 0.0005 to $0.0125 \mathrm{mg} / \mathrm{l}$; statistical differences of dose-response relationships of these samples have not been detected $(P=0.72)$, and the curves were thus unified to yield the baseline sensitivity (Fig. 2). After logit transformation, an $\mathrm{ED}_{50}$-value of $0.0065 \mathrm{mg} / \mathrm{l}$ kresoxim-methyl was determined for baseline sensitivity (Fig. 2, insert).

Since in vitro germination assays are performed by incubating the spores directly in fungicide suspensions, the field concentrations yielding the same effects must be higher. Determination of shifts in fungicide sensitivity in vitro does not allow a prediction of the magnitudes of the sensitivity shifts at which fungicide efficiencies would be insufficient in the field. Therefore, comparative in vivo studies with $V$, inaequalis conidia, collected in the untreated control orchard 2 in 1995 were performed. The results show that the $\mathrm{ED}_{50}$-value determined by measurement of diseased leaf area is 137 -fold, and that determined by counting the conidia formed is 104-fold higher than the $\mathrm{ED}_{50}$-value determined by in vitro germination assays (Fig. 3). The magnitude of a sensitivity shift in fungal populations necessary to affect fungicide efficiencies in the field has to exceed the safety margin, which was defined as the quotient of the recommended field concentration and the $E D_{90}$-value of the baseline sensitivity. Thus, a safety margin of 41 (measurement of diseased leaf area) or 80 (counting conidia formed) was found in the case of kresoxim-methyl at the recommended concentration of $62.5 \mathrm{mg} / \mathrm{l}$.

Twenty-seven kresoxim-methyl applications had been performed over 3 years in plot D of orchard 5 , and 54 applications of this fungicide had been performed over 6 years in orchard 6 , and no significant difference to baseline sensitivity was found using germination assays 
Table 3

$\mathrm{ED}_{50^{-}}$and $\mathrm{ED}_{90^{-}}$-values of Venturia inaequalis populations from control orchards for kresoxim-methyl. All values except those for multiplied conidia of orchard 2 were determined by in vitro

germination assays Baseline sensitivity represents the combination of all samples tested in vitro. Resistance factors are based on $\mathrm{ED}_{50}$-values

\begin{tabular}{|c|c|c|c|c|}
\hline Orchard & Sample & $\mathrm{ED}_{50}(\mathrm{mg} / \mathrm{l})$ & $\mathrm{ED}_{90}(\mathrm{mg} / 1)$ & Resistance-factor $\left(\mathrm{ED}_{50}\right)$ \\
\hline \multirow[t]{4}{*}{ Orchard 1} & conidia $1994^{\mathrm{b}}$ & 0.0015 & 0.011 & 0.24 \\
\hline & multiplied conidia $1994^{b}$ & 0.0035 & 0.013 & 0.53 \\
\hline & ascospores $1995^{\mathrm{b}}$ & 0.0005 & 0.011 & 0.07 \\
\hline & multiplied conidia $1995^{\mathrm{b}}$ & 0.0125 & 0.042 & 1.93 \\
\hline \multirow[t]{3}{*}{ Orchard 2} & multiplied conidia $1995^{\mathrm{b}}$ & 0.0045 & 0.031 & 0.69 \\
\hline & multiplied conidia $1995^{\circ}$ & 0.62 & 1.51 & \\
\hline & multiplied conidia $1995^{\mathrm{d}}$ & 0.47 & 0.78 & \\
\hline Orchard 3 & multiplied conidia $1994^{b}$ & 0.0100 & 0.059 & 1.54 \\
\hline \multirow[t]{2}{*}{ Orchard 4} & multiplied conidia $1994^{\mathrm{b}}$ & 0.0135 & 0.104 & 2.08 \\
\hline & ascospores $1995^{\mathrm{b}}$ & 0.0076 & 0.023 & 1.17 \\
\hline Baseline $^{b}$ & & 0.0065 & 0.042 & 1.00 \\
\hline
\end{tabular}

${ }^{a}$ Spore type and year of sampling; ${ }^{b}$ in vitro germination assay; ${ }^{\mathrm{c}}$ in vivo determination of portion of diseased leaf area; ${ }^{\mathrm{d}}$ in vivo determination of the number of conidia produced.

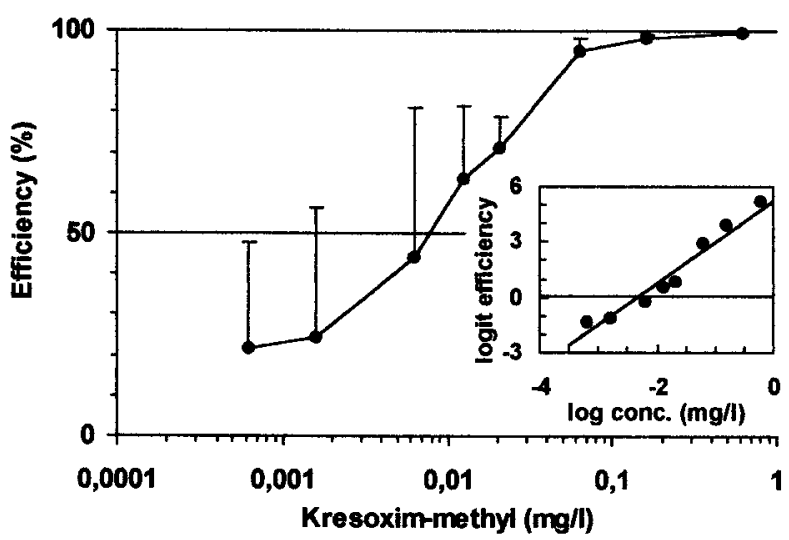

Fig. 2 Baseline sensitivity of Venturia inaequalis populations for kresoxim-methyl. In vitro germination assays were performed with eight samples from control orchards. Means of 32 microscope slides and standard deviations are given. The insert shows the logit transformed efficiency curve $(R=0.989)$; the point of intersection indicates an $E D_{50}$ of $0.0065 \mathrm{mg}$ kresoxim-methyl $/ \mathrm{l}$

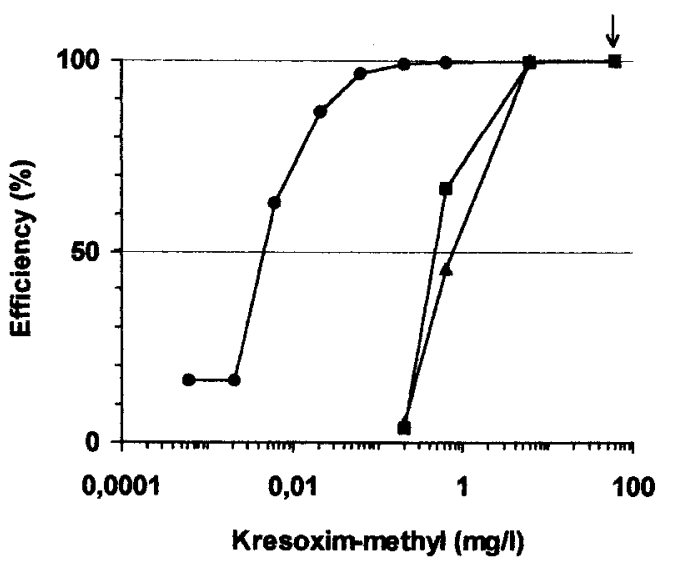

Fig. 3 Comparison of in vitro and in vivo sensitivity assays. Multiplied conidia of Venturia inaequalis collected from control orchard 2 in 1995 were used for in vitro germination assays $(\boldsymbol{O})$, and to determine diseased leaf area $(\boldsymbol{\square})$ or the number of conidia produced $(\boldsymbol{A})$ in the presence of kresoxim-methyl. The arrow indicates the recommended kresoximmethyl concentration
(Table 4). Conidia of orchard 6, which had been exposed to the most drastic selection pressure, were analysed with respect to diseased leaf area and the number of conidia formed. Again, no significant differences to baseline sensitivity were found.

\section{Sensitivity of $V$. inaequalis populations to anilinopyrimidine} fungicides

To determine the baseline sensitivity of $V$. inaequalis populations to pyrimethanil and cyprodinil, in vivo sensitivity tests were performed with conidia from orchard 1 , collected in 1994 and 1995 , and with conidia from orchard 2 of 1995. Dose-response relationships of these three samples showed no significant statistical difference for pyrimethanil $(\mathbf{P}=0.90)$, and for cyprodinil $(P=$ $0.66)$. The curves were thus combined to determine the baseline sensitivity (Figs 4, 5). Logit-transformation allowed the calculation of $\mathrm{ED}_{50}$-values of $35.5 \mathrm{mg} / 1 \mathrm{pyri}-$ methanil and of $14.5 \mathrm{mg} / 1$ cyprodinil (inserts of Figs 4 , 5).

With the recommended field concentrations of $300 \mathrm{mg} / \mathrm{l}$ pyrimethanil and $150 \mathrm{mg} / \mathrm{l}$ cyprodinil, fungicide efficiencies of $100 \%$ and $99 \%$ were found; the safety margin was 4.6 for pyrimethanil and 3.6 for cyprodinil.

Samples were collected from orchard 5 to evaluate shifts in the anilinopyrimidine sensitivities in $V$. inaequalis populations. In the pyrimethanil-treated plots $\mathrm{B}$ and $\mathrm{C}$, samples were taken in October 1994 (plot C) and in June and September 1995 (plot B). Dose-response relationships of these populations were not significantly different from the baseline sensitivity. Resistance factors for pyrimethanil were between 0.92 and 1.69 (Table 5).

In plot A, samples were taken in October 1994, June 1995 and July 1996 to analyse the cyprodinil sensitivity. Again, dose-response relationships indicated no significant differences as compared with the baseline sensitivity (Table 5), and after logit-transformation and determination of $\mathrm{ED}_{50}$-values, the resistance factors between 0.69 and 1.13 were calculated for this fungicide (Table 5).

Taken together, after 43 anilinopyrimidine treatments in plot A from 1993 to 1996, no shift in anilinopyrimidine sensitivity in $V$. inaequalis populations has been detected. 
Table 4

$\mathrm{ED}_{5_{0}}$-values and resistance

factors of Venturia inaequalis populations from kresoximmethyl-treated

orchards. All values were

determined by in

vitro germination assays

\begin{tabular}{lccc}
\hline Sample $^{\mathrm{a}}$ & $\mathrm{ED}_{\mathrm{s0}}(\mathrm{mg} / \mathrm{l})$ & Resistance-factor & P-value $^{\mathrm{b}}$ \\
\hline Baseline sensitivity & 0.0065 & & \\
& & & \\
Orchard 5 part D & 0.0117 & 1.8 & 0.148 \\
$\quad$ multiplied conidia 1994 & 0.0064 & 1.0 & 0.398 \\
ascospores 1995 & 0.0288 & 4.5 & 0.013 \\
multiplied conidia 1995 & 0.0240 & 3.7 & 0.102 \\
$\quad$ ascospores 1996 & 0.0081 & 1.3 & 0.790 \\
$\quad$ multiplied conidia 1996 & 0.0036 & 0.6 & 0.926 \\
Orchard 6: & & & \\
conidia 1996 & & & \\
\hline
\end{tabular}

archard, spore type and year of sampling; ${ }^{\mathrm{b}} \mathrm{P}$-value after comparison of the dose-response relationship of the sample with the baseline sensitivity using factorial analysis of ranks.

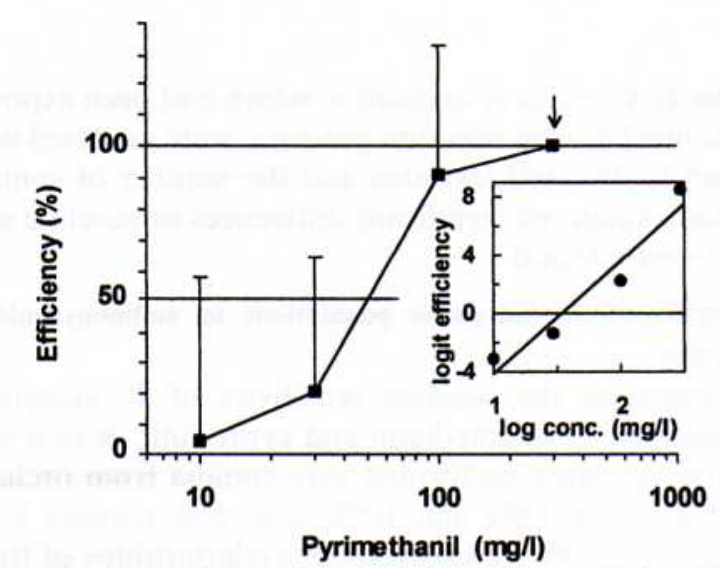

Fig. 4 Baseline sensitivity of Venturia inaequalis populations for pyrimethanil. Conidia collected from three different nontreated control orchards were used to determine fungicide sensitivity by microscopic in vivo analysis of conidiophores. A total of 24 leaves per fungicide concentration was examined. The arrow indicates the recommended pyrimethanil concentration. The insert shows the logit transformed efficiency curve $(R=0.966)$; the point of intersection indicates an $E D_{50}$ of $35.5 \mathrm{mg}$ pyrimethanil/1

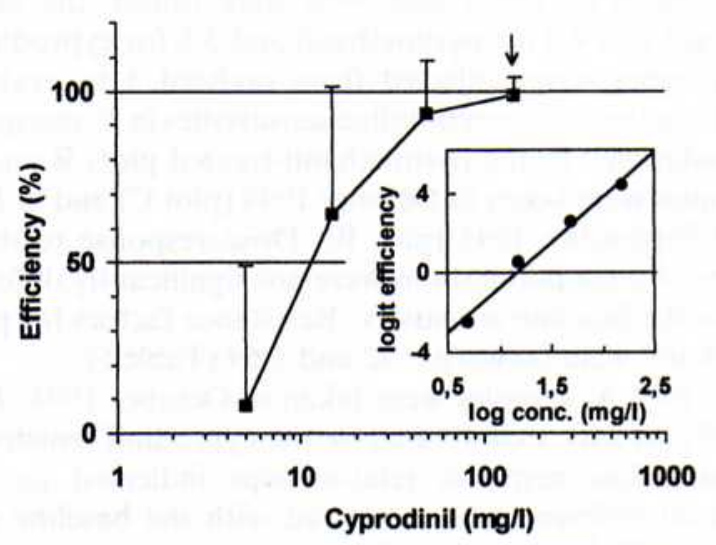

Fig. 5 Baseline sensitivity of Venturia inaequalis populations for cyprodinil. Conidia collected from three different nontreated control orchards were used to determine fungicide sensitivity by microscopic in vivo analysis of conidiophores. A total of 24 leaves per fungicide concentration was examined. The arrow indicates the recommended cyprodinil concentration. The insert shows the logit transformed efficiency curve $(R=0.991)$; the point of intersection indicates an $E D_{50}$ of $14.5 \mathrm{mg}$ cyprodinil $/ 1$

\section{Discussion}

Assays to analyse the sensitivity shifts in fungal populations must depend on the mode of fungicide action. Anilinopyrimidines act through inhibition of secretion of enzymes such as cutinases, lipases, invertases, and of cell wall-degrading enzymes. This group of fungicides thus exhibits a novel fungicidal mechanism (Milling and Richardson, 1995; Miura et al., 1994). Extracellular enzymes have been discussed to contribute to fungal virulence (Mendgen et al., 1996; Schäfer, 1994). Cutinases, pectic and cellulolytic enzymes have been demonstrated in $V$. inaequalis (Kollar, 1994; Köller et al., 1991; Valsangiacomo and Gessler, 1992), and these enzymes could play a critical role in the penetration and/or nutrient supply of the fungus (Kollar, 1997; MacHardy, 1996). Thus, the interference of anilinopyrimidines with enzyme secretion is consistent with the results obtained from microscopic analyses of fungal infection sites on fungicide-treated leaves (Fig. 1). While the formation of a penetration peg can often be observed, extended subcuticular development requiring enzyme secretion is completely blocked (Daniels et al., 1994; Knauf-Beiter et al., 1995). However, another suspected mode of action of these fungicides, i.e. the inhibition of methionine biosynthesis (Fritz et al., 1997; Masner et al., 1994) could also lead to the inhibition of subcuticular growth, as suggested in an early paper by Kline et al. (1957). These studies showed that mutants of $V$. inaequalis, deficient in methionine biosynthesis, were arrested after penetration of the cuticle and were not able to differentiate conidiophores and conidia. Exogenously applied methionine restored both subcuticular growth and conidiation (Kline etal., 1957). These results indicate that anilinopyrimidines affect the fungus-plant interaction, rather than saprophytic growth.

It has recently been shown that Colletotrichum and Fusarium species exhibit a targeted secretion of cutinolytic enzymes only during infection structure differentiation (Podila et al., 1995). However, $V$. inaequalis does not differentiate infection structures during growth on agar plates (Smith, 1991). Probably, an infectionrelated secretion of enzymes is not needed during growth on agar. Therefore, a possible inhibition of enzyme secretion may not inhibit growth on agar, as has been shown with Botryotinia fuckeliana. With this fungus, ani- 
Table 5

$\mathrm{ED}_{50}$-values and resistance

factors of Venturia inaequalis populations for

anilinopyrimidines. All values were

determined by microscopic

determination of

conidiophores in vivo

\begin{tabular}{|c|c|c|c|c|}
\hline Sample & Number of treatments ${ }^{b}$ & $\mathrm{ED}_{50}(\mathrm{mg} / \mathrm{l})$ & Resistance-factor & P-value ${ }^{\circ}$ \\
\hline \multicolumn{5}{|l|}{ Pyrimethanil } \\
\hline Baseline sensitivity & 0 & 35.5 & & \\
\hline \multicolumn{5}{|l|}{ Orchard 5 plot $C$} \\
\hline October 1994 & 8 & 60.0 & 1.69 & 0.92 \\
\hline \multicolumn{5}{|l|}{ Orchard 5 plot $B$} \\
\hline June 1995 & 9 & 33.9 & 0.95 & 0.77 \\
\hline September 1995 & 14 & 32.7 & 0.92 & 0.97 \\
\hline \multicolumn{5}{|l|}{ Cyprodinil } \\
\hline Baseline sensitivity & 0 & 14.5 & - & \\
\hline \multicolumn{5}{|l|}{ Orchard 5 plot $A$} \\
\hline October 1994 & 22 & 14.2 & 0.98 & 0.21 \\
\hline June 1995 & 30 & 16.4 & 1.13 & 0.31 \\
\hline July 1996 & 43 & 10.0 & 0.69 & 0.33 \\
\hline
\end{tabular}

a Orchard and month of sampling. Only conidia were evaluated; ${ }^{b}$ Number of pyrimidinamine treatments (pyrimethanil or cyprodinil) in the orchard since 1993; ${ }^{\mathrm{c}} \mathrm{P}$-value after comparison of the dose-response relationships of the sample with the baseline using factorial analysis of ranks. linopyrimidines only slightly reduced growth on nutrientrich media (Hilber and Schüepp, 1996; Masner et al., 1994). Obviously, in vitro assays may not reflect the situation in nature. Sensitive isolates could thus be falsely classified as resistant in in vitro assays, where infection structures are not differentiated (Birchmore et al., 1996). Therefore, the recent report of significant differences in the sensitivities of $V$. inaequalis isolates (Schnabel and Parisi, 1997) may not be valid under field conditions. The in vitro tests performed by these authors were done with spores growing on complex media which have been shown to lead to extended variations in fungicide sensitivity (Birchmore et al., 1996).

As a consequence, in vivo tests involving the host plants (Kunz et al., 1997; Siebels and Mendgen, 1994) are an absolute necessity to correctly investigate sensitivity shifts in $V$. inaequalis populations to anilinopyrimidine fungicides.

The results of the present study, based on microscopic in vivo analyses, indicate that, under the experimental conditions used, no reduced fungicide sensitivities were found in $V$. inaequalis populations, even after a total of 43 anilinopyrimidine applications in 4 years.

Birchmore et al. (1996) have reported that after 15 anilinopyrimidine applications in grapes over 5 years, no sensitivity shifts have been found in $B$. fuckeliana. However, after 8 years of cyprodinil application, reduced fungicide efficiencies to this fungus have been detected by Hilber and Schüepp (1996).

The strobilurin kresoxim-methyl specifically inhibits germination of $V$. inaequalis conidia (Gold et al., 1996). This inhibition is due to blocking of the electron transport at the cytochrome bcl-complex, and kresoxim-methyl can thus be regarded as an inhibitor of mitochondrial respiration (Becker et al., 1981; Mizutani et al., 1995). This high specificity and the fact that strobilurin A-producing fungi such as Strobilurus tenacellus and Mycena galopoda are insensitive to the drug, due to a single amino acid exchange in their cytochrome $b$, make the occurrence of fungicide resistance likely (Kraiczy et al., 1996). Also in the yeasts Saccharomyces cerevisiae and Schizosaccharomyces pombe, resistance has been shown to be mediated by amino acid exchange in the cytochrome molecule (DiRago et al., 1989; Kraiczy et al., 1996).

To measure the inhibition of germination the host plant is not required, and sensitivity tests can therefore be performed on microscope slides (Table 2) or agar plates (Smith, 1991). A disadvantage of this method is that in vitro the inhibitory concentrations are smaller than those determined in the field (Fig. 3), and from such experiments no conclusions concerning the magnitude of sensitivity shifts necessary to reduce the fungicide efficiency in the field can be drawn. It is therefore important to determine the safety margin by in vivo sensitivity tests on the plant. Measurements of the diseased leaf area or production of conidia would be appropriate in vivo assays.

In the present studies, the highest selection pressure has been applied in orchard 6. Fifty-four kresoxim-methyl treatments have been performed in 6 years, but no significant difference from baseline sensitivity was found in germination assays and in vivo assays based on diseased leaf area or production of conidia. This indicates that a shift in sensitivity did not occur. To reduce efficiency in the field, a sensitivity shift by a factor of 40 would be needed. The highest resistance factor found in the field, however, was 4.5.

So far, resistance in $V$. inaequalis populations to strobilurins or anilinopyrimidines has not been described. In the present investigations, these fungicides have been tested in comparatively small apple scab populations, and treatment with these fungicides was carried out in a limited time frame of 4 and 6 years, respectively. This, as indicated by the studies by Birchmore et al. (1996) and Hilber and Schüepp (1996), may not be sufficient for resistance to develop in a fungal population. Under conditions of agricultural practice, however, the fungal population would be significantly larger, and fungicide application would occur over a longer time than in the present investigations. These factors may drastically increase the probability of selection of isolates with reduced sensitivity to strobilurins or anilinopyrimidines (Scheinpflug, 1988; Veverka, 1996).

Based on these considerations, it cannot be concluded 
that resistance to the new fungicides tested in this paper is unlikely to occur. However, these fungicides registered for $V$. inaequalis control will certainly be of value, especially in combinations with other fungicides. Alternate application of fungicides with different modes of inhibition will help to reduce the risk of resistance occurring. In addition, since the anilinopyrimidines are curative fungicides, they could be used in combination with DMIs in integrated disease control and would thus help to reduce the overall amount of chemicals applied in the field.

\section{Acknowledgements}

The authors thank BASF AG, Limburgerhof, for donation of kresoximmethyl (BAS $490 \mathrm{~F}$ ) and apple leaf samples from the test orchard in Bavendorf. Ciba-Geigy GmbH, Frankfurt, and AgrEvo GmbH, Düsseldorf, which provided test preparations of cyprodinil (CGD $20470 \mathrm{~F}$ ) and pyrimethanil (SCH $32050 \mathrm{~F}$ ). They especially thank E. Lange, Übergebietliche Pflanzenschutzberatung Überlingen, for the supply of apple leaf samples from test orchards, and for stimulating discussions.

\section{Literature}

Becker, W. F., G. von Jagow, T. Anke, W. Steglich (1981): Oudemansin, strobilurin A, strobilurin B and myxothiazol: new inhibitors of the $b_{1}$ segment of the respiratory chain with an e- $\beta$-methoxyacrylate system as common structural element. FEBS Lett. 132, 329-333.

Birchmore, R. J., R. J. Williams, R. J. Milling, P. E. Russell (1996): Development of methods for monitoring populations of Botrytis cinerea for sensitivity to pyrimethanil. In: Lyr, H., P. E. Russel and H. D. Sisler (eds), Modern Fungicides and Antifungal Compounds, pp. 377-385. Intercept Ltd, Andover, UK

Dahmen, H., T. Staub (1992): Protective, curative, and eradicant activity of difenoconazole against Venturia inaequalis, Cercospora arachidicola, and Alternaria solani. Plant Dis. 76, 774-777.

Daniels, A., R. J. Birchmore, E. H. Winter (1994): Activity of pyrimethanil on Venturia inaequalis. Proc. Br. Crop. Prot. Conf. - Pests Dis. 4, 525-532.

DiRago, J.-P., J.-Y. Coppée, A.-M. Colson (1989): Molecular basis for resistance to myxothiazol, mucidin (strobilurin A), and stigmatellin. J. Biol. Chem. 264, 14543-14548.

Fehrmann, H. (1976): Systemische Fungizide-ein Überblick II. Fungizidresistenz phytopathogener Pilze. J. Phytopathol. 86, 144-185.

Fritz, R., C. Lanen, V. Colas, P. Leroux (1997): Inhibition of methionine biosynthesis in Botrytis cinerea by the anilinopyrimidine fungicide pyrimethanil. Pestic. Sci. 49, 40-46.

Gilpatrick, J. D. (1982): Case study 2: Venturia of pome fruits and Monilinia of stone fruits. In: Dekker J. and S. G. Georgopoulos (eds) Fungicide Resistance in Crop Protection, pp. 195-206. Centre for Agricultural Publishing and Documentation, Wageningen.

Gold, R. E., E. Ammermann, H. Köhle, G. M. E. Leinhos, G. Lorenz, J. B. Speakman, M. Stark-Unnau, H. Sauter (1996): The synthetic strobilurin BAS $490 \mathrm{~F}$ : profile of a modern fungicide. In: Lyr, H., P. E. Russel and H. D. Sisler (eds), Modern Fungicides and Antifungal Compounds, pp. 79-92. Intercept Ltd, Andover, UK.

Heye, U. J., J. Speich, H. Siegle, R. Wohlhauser, A. Hubele (1994) CGA 219417-A novel broad-spectrum fungicide. Proc. Br. Crop. Prot. Conf. - Pests Dis. 4, 501-508.

Hilber, U. W., H. Schüepp (1996): A reliable method for testing the sensitivity of Botryotinia fuckeliana to anilinopyrimidines. Pestic. Sci. 47, 241-247.

Hildebrand, P. D., C. L. Lockhart, R. J. Newberry, R. G. Ross (1988): Resistance of Venturia inaequalis to bitertanol and other demethylation-inhibiting fungicides. Can. J. Plant Pathol. 10, 311-316.

Kiebacher, J., G. M. Hoffmann (1980): Qualitative and quantitative Untersuchungen zur Resistenz von Venturia inaequalis gegen Benzimidazol-Fungizide. Z. PflKrankh. PflSchutz 87, 705-716.

Kline, D. M., D. M. Boone, G. W. Keitt (1957): Venturia inaequalis (Cke.) Wint. XIV. Nutritional control of pathogenicity of certain induced biochemical mutants. Am. J. Bot. 44, 797-803.

Knauf-Beiter, G., H. Dahmen, U. Heye, T. Staub (1995): Activity of cyprodinil: optimal treatment timing and site of action. Plant Dis. 79, 1089-1103.

Kollar, A. (1994): Characterization of specific induction, activity, and isozyme polymorphism of extracellular cellulases from Venturia inaequalis detected in vitro and on the host plant. Mol. Plant-Microbe Interact. 7, 603-611.

Kollar, A. (1997): Aktuelle Forschung an dem bedeutendsten Erreger im Apfelanbau, dem Apfelschorfpilz Venturia inaequalis. Nachrichtenbl. Deut. Pflanzenschutzd. 49, 131-136.

Köller, W., D. M. Parker, C. M. Becker (1991): Role of cutinase in the penetration of apple leaves by Venturia inaequalis. Phytopathology 81, 1375-1379.

Köller, W., W. F. Wilcox, J. Barnard, A. L. Jones, P. G. Braun (1997): Detection and quantification of resistance of Venturia inaequalis populations to sterol demethylation inhibitors. Phytopathology 87, 184-190.

Kraiczy, P., U. Haase, S. Gencic, S. Flindt, T. Anke, U. Brandt, G. von Jagow (1996): The molecular basis for the natural resistance of the cytochrome $b_{1}$ complex from strobilurin-producing basidio-

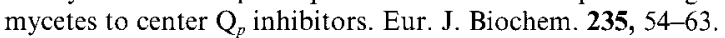

Kunz, S., H. Deising, K. Mendgen (1997): Acquisition of resistance to sterol demethylation inhibitors by populations of Venturia inaequalis. Phytopathology 87, 1272-1278.

MacHardy, W. E. (1996): Apple Scab., pp. 161-162, APS Press, St. Paul, MN.

Masner, P., P. Muster, J. Schmid (1994): Possible methionine biosynthesis inhibition by anilinopyrimidine fungicides. Pestic. Sci.42, 163-166.

Meddis, R. (1984): Statistics Using Ranks: A Unified Approach, pp 299-345, Basil Blackwell Publisher Ltd., Oxford.

Mendgen, K., M. Hahn, H. Deising (1996): Morphogenesis and mechanisms of penetration by plant pathogenic fungi. Ann. Rev. Phytopathol. 34, 367-386.

Milling, R. J., C. J. Richardson (1995): Mode of action of the anilinopyrimidine fungicide Pyrimethanil. 2. Effects on enzyme secretion in Botrytis cinerea. Pestic. Sci, 45, 43-48.

Miura, I., T. Kamakura, S. Maeno, S. Hayashi, I. Yamaguchi (1994): Inhibition of enzyme secretion in plant pathogens by Mepanipyrim, a novel fungicide. Pestic. Biochem. Phyisiol. 48, 222-229.

Mizutani, A., H. Yukioka, H. Tamura, N. M. Iki, M. Masuko, R. Takeda (1995): Respiratory characteristics in Pyricularia oryzae exposed to a novel alkoxyiminoacetamide fungicide. Phytopathology 85, 306-311.

Neter, J., W. Wassermann, M. H. Kutner (1983): Applied Linear Regression Models, pp. 362-367, Richard D. Irwin, Inc, Homewood IL.

Podila, G. K., E. Rosen, M. J. D. S. Francisco, P. E. Kollatukudy (1995): Targeted secretion of cutinase in Fusarium solani f. sp. pisi and Colletotrichum gloeosporioides. Phytopathology 85, 238-242.

Schäfer, W. (1994): Molecular mechanisms of fungal pathogenicity to plants. Ann. Rev. Phytopathol. 32, 461-477.

Scheinpflug, H. (1988): History of DMI fungicides and monitoring for resistance. In: Delp C. J. (ed.), Fungicide Resistance in North America, pp. 77-78. American Phytopathological Society, St. Paul, MN.

Schnabel, G., L. Parisi (1997): Sensitivity of Venturia inaequalis to five DMI fungicides, including the new triazole fluquinconazole, and to pyrimethanil. Z. PflKrankh. PfiSchutz 104, 3646.

Siebels, C., K. Mendgen (1994): A microscopic evaluation of the sensitivity of Venturia inaequalis populations to sterol demethylation inhibitors. Mycol. Res. 98, 619624.

Smereka, K. J., W. E. MacHardy, A. P. Kausch (1987): Cellular differentiation in Venturia inaequalis ascospores during germination and penetration of apple leaves. Can. J. Bot. 65, 2549-2561.

Smith, C. M. (1991): In vitro methods for monitoring flusilazole sensitivity in populations of Venturia inaequalis (apple scab) and Cercosporidium personatum (peanut late leaf spot). EPPO-Bulletin 21, 323-328.

Smith, F. D., D. M. Parker, W. Köller (1991): Sensitivity distribution of Venturia inaequalis to the sterol demethylation inhibitor flusilazole baseline sensitivity and implications for resistance monitoring. Phytopathology 81, 392-396.

Valsangiacomo, C., C. Gessler (1992): Purification and characterization of an exo-polygalacturonase produced by Venturia inaequalis, the causal agent of apple scab. Physiol. Molec. Plant Pathol. 40, 63-77.

Veverka, K. (1996): General concepts of fungicide resistance. In: Lyr, H, P. E. Russel and H. D. Sisler (eds), Modern Fungicides and Antifungal Compounds, pp. 283-292. Intercept Ltd, Andover, UK. 